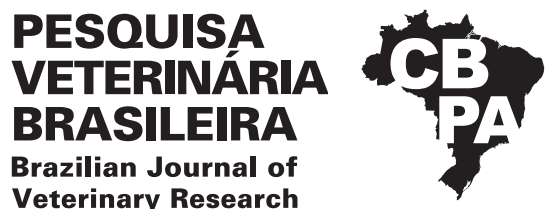

Pesq. Vet. Bras. 41:e06670, 2021

DOI: 10.1590/1678-5150-PVB-6670

Original Article

Small Animal Diseases

ISSN 0100-736X (Print)

ISSN 1678-5150 (Online)

\title{
Occurrence and molecular characterization of Giardia duodenalis from naturally infected dogs in the municipality of Santa Maria, Rio Grande do Sul, Brazil ${ }^{1}$
}

\author{
Vanessa Osmari ${ }^{2}$ (D), Marta Elena M. Alves², Fernando S. Rodrigues ${ }^{3}$, \\ Patrícia Bräunig ${ }^{2}$ (D) Juliana F. Cargnelutti ${ }^{2}$, Fernanda S.F. Vogel ${ }^{2}$, \\ Sônia A. Botton ${ }^{2}$ and Luís Antônio Sangioni ${ }^{2 *}$
}

\begin{abstract}
Osmari V., Alves M.E.M., Rodrigues F.S., Bräunig P., Cargnelutti J.F., Vogel F.S.F., Botton S.A. \& Sangioni L.A. 2021. Occurrence and molecular characterization of Giardia duodenalis from naturally infected dogs in the municipality of Santa Maria, Rio Grande do Sul, Brazil. Pesquisa Veterinária Brasileira 41:e06670, 2021. Departamento de Medicina Veterinária Preventiva, Centro de Ciências Rurais, Universidade Federal de Santa Maria, Av. Roraima 1000, Prédio 63C, Bairro Camobi, Santa Maria, RS 97105-900, Brazil. E-mail: lasangioni@gmail.com

Giardiasis is an important and prevalent zoonosis in dogs and humans caused by Giardia spp. The close relationship between pets and humans has physical, emotional and social benefits. The dogs have an important role in Giardia duodenalis cycle and transmission. This study aimed to verify the occurrence of the parasite in dogs from Central Region, in Santa Maria, Rio Grande do Sul State, Brazil, from April to October 2018. Dog feces (230) were submitted to Faust coproparasitological and molecular analyses. The positive samples in the nested-PCR ( $\beta$-giardin gene) were sent for DNA sequencing and phylogenetic analyses (Neighbor-Joining). The occurrence of G. duodenalis, was 5.6\% (13/230) and 4.3\% (10/230) detected by coproparasitological technique and nested-PCR, respectively. There was no difference in the sensitivity of the tests used. From the faecal samples analyzed, there were no differences among the variables: diagnostic techniques, local, sex, and age of the animals $(p>0.05)$. Only in the stool examination methodology a difference was observed between the ages $(p<0.05)$. G. duodenalis assemblages were $\mathrm{C}$ and $\mathrm{D}$, frequently reported in dogs. The close relationship between dogs and people may allow co-infections of circulating parasites in the population, including Giardia spp. and increasing the risk of transmission of zoonotic agents.
\end{abstract}

INDEX TERMS: Molecular characterization, Giardia duodenalis, infection, dogs, Brazil, protozoa, giardiasis, nested-PCR, phylogeny.

RESUMO.- [Ocorrência e caracterização molecular de Giardia duodenalis em cães naturalmente infectados no município de Santa Maria, Rio Grande do Sul, Brasil.] A giardíase é uma zoonose importante e prevalente em cães e humanos, sendo causada por Giardia spp. A estreita relação

\footnotetext{
${ }^{1}$ Received on March 12, 2021.

Accepted for publication on March 26, 2021.

${ }^{2}$ Laboratório de Doenças Parasitárias (LADOPAR), Departamento de Medicina Veterinária Preventiva (DMVP), Centro de Ciências Rurais (CCR), Universidade Federal de Santa Maria (UFSM), Av. Roraima 1000, Prédio 63C, Bairro Camobi, Santa Maria, RS 97105-900, Brazil. *Corresponding author: lasangioni@gmail.com

${ }^{3}$ Departamento de Medicina Veterinária Preventiva, Centro de Ciências Agrárias (CCA), Universidade Estadual de Londrina (UEL), Jardim Bandeirante, Jardim Portal de Versalhes 1, Londrina, PR 86057-970, Brazil.
}

entre animais de estimação e seres humanos traz benefícios físicos, emocionais e sociais. Os cães têm um papel importante no ciclo e transmissão de Giardia duodenalis. Este estudo teve como objetivo verificar a ocorrência do parasita em cães da Região Central, em Santa Maria, RS, Brasil, de abril a outubro de 2018. As fezes de cães (230) foram submetidas a técnica coproparasitológica de Faust e análises moleculares. As amostras positivas no nested-PCR (gene $\beta$-giardin) foram enviadas para sequenciamento de DNA e posterior análise filogenética (Neighbor-Joining). A ocorrência de G. duodenalis foi de 5,6\% (13/230) e 4,3\% (10/230) detectados pela técnica coproparasitológica e nested-PCR, respectivamente. Não houve diferença na sensibilidade dos testes utilizados. Das amostras fecais analisadas, não houve diferenças entre as variáveis: técnicas de diagnóstico, local, sexo e idade dos 
animais $(p>0,05)$. Somente na metodologia de exame de fezes observou-se diferença entre as idades $(p<0,05)$. As assemblages de G. duodenalis encontradas foram C e D, frequentemente relatadas em cães. A estreita relação entre cães e pessoas pode permitir co-infecções de parasitas circulantes na população, incluindo Giardia spp. e aumentando o risco de transmissão de agentes zoonóticos.

TERMOS DE INDEXAÇÃO: Caracterização molecular, Giardia duodenalis, cães, infecção, Brasil, protozoário, giardíase, nestedPCR, filogenia, caninos.

\section{INTRODUCTION}

Giardiasis is an important parasitic infection of dogs and is one of the most common parasitic diseases affecting humans (Katagiri \& Oliveira-Sequeira 2008). The etiological agent of giardiasis is a flagellate protozoan belonged to Giardia genus (Plutzer et al. 2010). Six species of Giardia have been identified: G. duodenalis, G. muris, G. microti, G. ardeae, G. psittaci, and G. agilis. G. duodenalis infects a wide range of mammals, including humans, production animals and companion animals, making it the only species of interest with regard to public health and zoonosis (Read et al. 2004). G. duodenalis is acknowledged as a complex of at least eight different assemblages with different hosts: A and B are found in humans and several domestic and wild mammals, $\mathrm{C}$ and $\mathrm{D}$ are specific for dogs and other canids, $\mathrm{E}$ is present in farm animals, $\mathrm{F}$ in felids, $\mathrm{G}$ in rats, and $\mathrm{H}$ in marine mammals (Cacciò 2015).

This agent is transmitted by direct contact, water, food, or other materials contaminated with Giardia spp. cysts in the feces (Mundim et al. 2001, Andresiuk et al. 2003, Blazius et al. 2005). In dogs, anorexia, weight loss, anemia, diarrhea, and dehydration can be observed, affecting animals of any age (Ankarklev etal. 2010). The prevalence of G. duodenalis in dogs has variable indices, depending on the geographic location, the method used for the diagnosis and the population studied (Collins et al. 1987, Nikolic et al. 1993, Marcel et al. 1994).

The coprological technique of flotation in $33 \%$ zinc sulphate (Faust et al. 1939) has been described as the best method for the identification of cysts and trophozoites of Giardia spp. (Bartmann \& Araújo 2004). In addition, PCR techniques are used for the DNA detection of this protozoan (Barutzki et al. 2000). Currently, there is no "gold standard" test for detection of $G$. duodenalis, however molecular detection has been shown to be more specific and sensitive than coprological tests (Cacciò \& Ryan 2008, Ryan \& Cacciò 2013).

Dogs are able to harbor the assemblages A, B, C, and D (Feng \& Xiao 2011), and have an important role in the life cycle and transmission of $G$. duodenalis. This study was designed to evaluate the occurrence of the protozoan by comparing tests usually used in the diagnosis and to perform the phylogenetic analysis of isolates obtained from naturally infected dogs in the municipality of Santa Maria, Rio Grande do Sul, Brazil.

\section{MATERIALS AND METHODS}

Samples. In this study were evaluated 230 fecal samples from dogs obtained from April and October 2018. Of these samples, 10 were obtained from routine coproparasitological examinations carried out at the "Laboratório de Doenças Parasitárias" (LADOPAR) at "Universidade Federal de Santa Maria” (UFSM), 74 were collected in three commercial kennels and 146 were collected at Veterinary Hospital of UFSM, all located in the Central Region, in Santa Maria

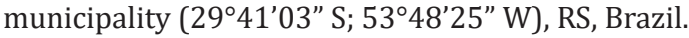

Fecal analysis. All samples were processed using Faust's technique (Faust et al. 1939). Each sample was analyzed in duplicate and evaluated by optical microscopy (at 100 and 400X magnification) to detect the presence of cysts and/or trophozoites of Giardia spp.

Total DNA extraction. All of the fecal samples were frozen in liquid nitrogen at $-196^{\circ} \mathrm{C}$, then thawed in $95^{\circ} \mathrm{C}$ water bath for 5 cycles of 5 minutes each, to facilitate the rupture of the cyst walls and the release of DNA. Total DNA extraction was performed with $200 \mathrm{mg}$ of feces, using the Purelink ${ }^{\circledR}$ Genomic DNA Mini Kit (Invitrogen, USA), following the recommendations of the manufacturer. After total DNA extraction, the concentration obtained from each sample was measured using a NanoDrop ${ }^{\circledR} 1000$ spectrophotometer (absorbance of 260/280 nm ratio for purity evaluation) (Thermo Scientific, USA). All samples were stored at $-20^{\circ} \mathrm{C}$ until the molecular assays were performed.

Molecular detection. The partial amplification of the $\beta$-giardin $(b g)$ gene, which expresses a surface protein of the parasite's ventral disc, was performed based on a nested-PCR using specific primers for this protozoan (Faubert 2000, Cacciò et al. 2002, Lalle et al. 2005). In the first reaction, forward primer - G7 (5'-AAGCCCGACGACCTCACCCGCAGTGC-3') and reverse primer - G759 (5'-GAGGCCGCCCTGGATCTTCGAGACGAC-3') were used, amplifying 753 bp (base pair) fragments (Cacciò et al. 2002). In the second reaction, forward BG-Nst-F (5'-GAACGAACGAGATCGAGGTCCG-3') and reverse BG-Nst-R (5'-CTCGACGAGCTTCGTGTT-3') primers were used, amplifying $511 \mathrm{bp}$ fragments (Lalle et al. 2005).

The first amplification reaction was prepared using $5 \mu \mathrm{L} 5 \mathrm{X}$ buffer, $0.2 \mu \mathrm{M}$ of each primer, $0.28 \mathrm{mM}$ deoxynucleotide triphosphates (dNTPs) (Kapa, Bio Systems, Boston/MA, USA), 1U Taq enzyme GoTaq ${ }^{\circledR}$ DNA Polymerase (Hot Start Polymerase, Promega, Madison/ WI, USA), $1.5 \mathrm{mM} \mathrm{MgCl}_{2}, 30 \mathrm{ng} / \mu \mathrm{L}$ template DNA, and MilliQ water to a final volume of $25 \mu \mathrm{L}$. The second reaction was prepared using the same enzyme buffer, primers (BG-Nst-F and BG-Nst-R), dNTPs, Taq DNA Polymerase and $\mathrm{MgCl}_{2}$ concentrations, plus $1 \mu \mathrm{L}$ of the PCR amplified product from the first reaction, to make a final volume of $25 \mu \mathrm{L}$. The amplification conditions for both reactions were as follows: initial denaturation at $94^{\circ} \mathrm{C}$ for 5 minutes, denaturation at $94^{\circ} \mathrm{C}$ for 30 seconds, followed by 35 annealing cycles at $60^{\circ} \mathrm{C}$ for 45 seconds, extension at $72^{\circ} \mathrm{C}$ for 1 minute, and a final extension at $72^{\circ} \mathrm{C}$ for 7 minutes, ending the PCR cycles at $4^{\circ} \mathrm{C}$.

In all reactions, MilliQ water was used as negative control. A DNA sample positive for Giardia spp. obtained from the "Laboratório de Protozoologia" at "Universidade Estadual de Londrina" (UEL), Londrina, Paraná State, Brazil, was used as a positive control. All PCR products from both reactions were submitted to $1.5 \%$ agarose gel electrophoresis, visualized in ultraviolet light and photo documented.

PCR inhibition test. To confirm if inhibition of the reaction occurred in the negative samples in the PCR, $1 \mu \mathrm{L}$ of DNA from a positive sample was added to $1 \mu \mathrm{L}$ of DNA from negative samples and the nested-PCR was performed under the same conditions mentioned above.

Gene sequencing and phylogenetic analysis. For the DNA sequencing, a nested-PCR reaction with a final volume of $50 \mu \mathrm{L}$ was performed using the same primers used to amplify the $b g$ gene. Positive PCR products from the second amplification reaction were purified with QIAquick ${ }^{\circledR}$ PCR Purification Kit (Qiagen ${ }^{\mathrm{TM}}$, Germany) according to the manufacturer's instructions. The purified final DNA was analyzed using a NanoDrop 1000 spectrophotometer (ThermoScientific, USA) to determine the concentration. After purification of the second round of nested-PCR product, DNA sequencing reactions were 
performed using 5 pmol of internal primers (forward BG-Nst-F and reverse BG-Nst-R) separately, 30-60ng of purified PCR product and MilliQ water to a final volume of $6 \mu \mathrm{L}$. The samples were placed in an incubator at $60^{\circ} \mathrm{C}$ for 2 hours for dehydration and finally sent for DNA sequencing (ACTGENE - Sequencing Service, Brazil). The results obtained from the sequencing were analyzed using Standen Package software ${ }^{4}$ and the nucleotide sequences were evaluated by comparing with existing DNA sequences (for the $b g$ gene) in the GenBank NCBI database BLAST search ${ }^{5}$. The DNA sequences obtained were used for the phylogenetic analyses of Giardia spp. isolates.

The neighbor-joining (NJ) method substitution model with maximum likelihood (Saitou \& Nei 1987) was employed for the phylogenetic analyses using a bootstrap of 1000 replicates (Felsenstein 1985). Evolutionary distances were calculated using the Jukes-Cantor method (Jukes \& Cantor 1969). Molecular Evolutionary Genetic Analysis (MEGA) software 10.0 was used to illustrate phylogenetic relationships (Kumar et al. 2018).

Reference sequences used were sub assemblages A1: KJ027411 and M36728; A2: AY072723; A3: AY072724; B1: AY072725; B2: AY072726; B3: AY072727 and B4: AY072728; assemblage C: AY545646,
JF422718, JF422720, JX867768, KY979498, LC316658; assemblage D: AY545647, EF455597, JF958105, KJ027423, LC316659; assemblage E: LC095675 and MG873353, F: AY647264 and JF958118; and assemblage G: EU769221 and MF671920. Giardia psittaci AB714977 was used as out-group to root the tree.

Statistical analysis. Statistical analysis was performed using R Core Team software (R Core Team 2016). The results were calculated using the Fisher Exact test, with a significance level of 5\% $(p<0.05)$.

\section{RESULTS}

The occurrence of Giardia spp. in the studied location was $5.6 \%(13 / 230)$ and $4.3 \%(10 / 230)$ as detected by the coproparasitological technique and nested-PCR, respectively. There was no significant difference in the results found ( $p>0.05)$, and there was no difference in the sensitivity between the tests evaluated. Statistical difference was only found in the Faust technique when comparing ages of $\operatorname{dog}(p<0.05)$ (Table 1 and 2$)$. The $p$ value for the Faust technique was 0.0202 when comparing the ages of the animals (0-1, 1-4, 4-10 and >10 years).

Table 1. Occurrence of Giardia spp. detected by Faust and nested-PCR methods in fecal samples of naturally infected dogs from Santa Maria, Rio Grande do Sul State, in South Brazil, according to origin, sex and age variables of the dogs

\begin{tabular}{|c|c|c|c|c|c|c|}
\hline \multirow{2}{*}{ Variable } & \multicolumn{2}{|c|}{ Faust } & \multicolumn{2}{|c|}{ Nested-PCR* } & \multicolumn{2}{|c|}{$\mathrm{X}^{2}(p$ value $)$} \\
\hline & Positive & $(\%)$ & Positive & $(\%)$ & Faust & Nested-PCR \\
\hline \multicolumn{7}{|l|}{ Origin } \\
\hline Kennel ( $n=74)$ & 4 & 5.4 & 4 & 5.4 & 0.6518 & 0.8321 \\
\hline LADOPAR $(\mathrm{n}=10)$ & 1 & 10 & - & - & & \\
\hline HVU $(n=146)$ & 8 & 5.4 & 6 & 4.1 & & \\
\hline \multicolumn{7}{|l|}{ Sex } \\
\hline Male $(n=124)$ & 6 & 4.8 & 6 & 4.8 & 0.5812 & 0.7563 \\
\hline Female $(n=106)$ & 7 & 6.6 & 4 & 3.7 & & \\
\hline \multicolumn{7}{|l|}{ Age } \\
\hline 0 months to 1 year $(n=50)$ & 7 & 14 & 6 & 12 & 0.0202 & 0.0530 \\
\hline 1 to 4 years $(n=73)$ & 1 & 1.3 & 2 & 2.7 & & \\
\hline 4 to 10 years $(n=62)$ & 2 & 3.2 & 1 & 1.6 & & \\
\hline$>10$ years $(n=45)$ & 3 & 6.7 & 1 & 2.2 & & \\
\hline
\end{tabular}

Table 2. Positive isolates of Giardia duodenalis identified according to origin of sample, sex of dog, age of dog and assemblages obtained by nested-PCR from samples of naturally infected dogs from Santa Maria, Rio Grande do Sul State, in South Brazil

\begin{tabular}{ccccc}
\hline Sample ID\# & Origin of samples* & Sex & Age (months) & Assemblage \\
\hline 93443 & HVU & Male & 24 & D \\
93518 & HVU & Female & 48 & D \\
90702 & HVU & Female & 2 & D \\
92838 & HVU & Female & 2 & D \\
93525 & HVU & Female & 168 & C \\
92890 & HVU & Female & 7 & C \\
2 & Kennel & Male & 7 & C \\
3 & Kennel & Female & 5 & C \\
5 & Kennel & Male & 24 & C \\
8 & Kennel & Male & C
\end{tabular}

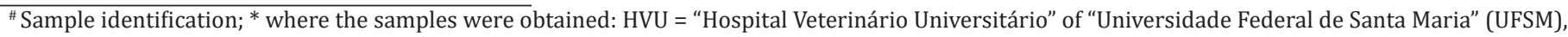
Santa Maria/RS, Kennel = commercial kennels.

4 Available at <http://staden.sourceforge.net/>

5 Available at <http://www.ncbi.nlm.nih.gov/BLAST> 
There were no differences in the occurrence of Giardia duodenalis in relation to sex ( $p>0.05)$ and age categories ( $p>0.05)$.

All positives samples in the nested-PCR were successfully sequenced for the $b g$ gene and phylogenetically, six sequences of $G$. duodenalis isolates were classified in assemblage $C$ and four sequences were classified in assemblage D (Fig.1).

\section{DISCUSSION}

The occurrence of Giardia spp. in this study it was 5.6\% (13/230) and $4.3 \%(10 / 230)$ as detected by the coproparasitological technique and nested-PCR, respectively. Occurrence results can be attributed to the single collection of feces from each animal, it being difficult to contact the owners of these dogs for subsequent sampling. For a precise diagnosis, it is important to use high sensitivity techniques, since most parasitized animals do not show clinical signs (Thompson et al. 2000). Due to the pattern of intermittent cystic elimination, especially in the chronic phase of infection, multiple fecal samples from the same animal should be analyzed on alternate days or from several animals sharing the same facilities (Geurden et al. 2010).

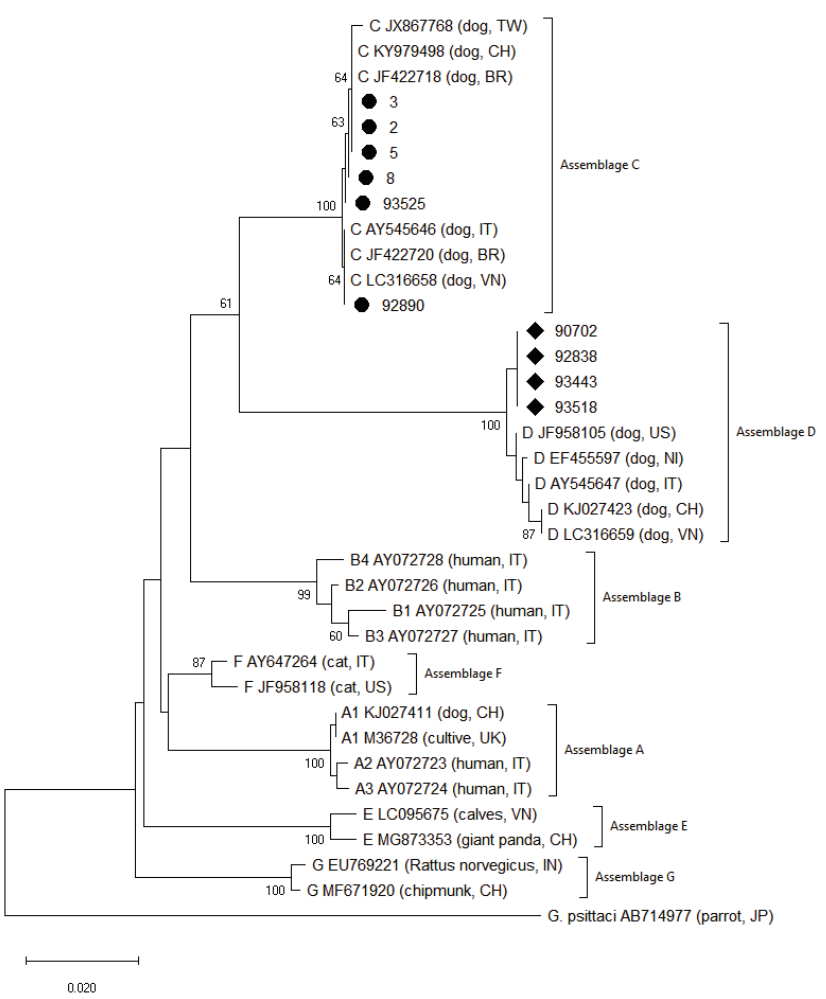

Fig.1. Neighbor-joining (NJ) tree based on sequence analyses of $\beta$-giardin $(b g)$ gene showing relationships among clinical isolates of Giardia duodenalis from dogs. The bootstrap values expressed as percentages based on 1000 replicates are present at their corresponding assemblages. The gene fragment used to compare the samples in this study was $483 \mathrm{bp}$. The isolates from this study are represented as 0 (assemblage C) and (assemblage D). Country of origin of the sequences used for the phylogenetic tree: Brazil (BR), China (CH), India (IN), Italy (IT), Japan (JP), Nicaragua (NI), Taiwan (TW), United Kingdom (UK) and Vietnam (VN). An out-group to root the tree was used: Giardia psittaci (AB714977).
One of the most commonly used coproparasitological methods in the diagnosis of Giardia duodenalis and other parasites is centrifugal-flotation with zinc sulfate (Faust et al. 1939). This technique allows protozoans, especially those that produce cysts, to float in the $\mathrm{ZnSO}_{4}$ solution due to their high density (1.18 specific gravity) and this salt solution does not distort or break the cyst wall (Joffe et al. 2011). In our study, we found a statistical difference only in relation to the Faust technique when comparing ages, with a $p$ value of $0.0202(p<0.05)$.

Mundim et al. (2003) observed a higher prevalence of the parasite in 100 dogs evaluated, where 41 (41\%) were positive using Faust's technique. These animals were from commercial kennels in the city of Uberlândia, Minas Gerais, Brazil, where there was a greater direct contact among the animals, thus facilitating the transmission of this protozoan. In the south of Brazil, in a study carried out in the city of Canoas using the Faust test and Auramine staining technique, of the 332 samples collected from canine feces, 34\% (113/332) were positive for Giardia spp. (Beck et al. 2005). In Caxias do Sul/RS, of the 77 canine fecal samples tested, only 5.2\% (4/77) were positive using the Faust technique (Brinker et al. 2009). In a previous study in Santa Maria, of the 240 samples of canine feces collected and examined through Faust's technique, 12.8\% (29/240) were positive for Giardia spp. (Silva et al. 2007). The reported studies employed only coproparasitological techniques. The varying percentages found in the different studies are probably due to the intermittent elimination of cysts in the feces and the different diagnostic techniques used.

No differences were observed in the occurrence of $G$. duodenalis using the Faust or Nested-PCR technique. Although there was no significant difference in this research in malefemale infection rates for the protozoan, Oliveira-Sequeira \& Amarante (2002) found a higher occurrence in adult males when compared to adult females. The authors showed that castrated dogs tended to show a reduced prevalence of infection compared to sexually active animals. On the other hand, Horejs \& Koudela (1994) observed that there was a higher frequency of Giardia spp. in females compared to males (7\% and $3.4 \%$, respectively), which was attributed to the greater susceptibility of females to infection during pregnancy and the puerperal period. On the basis of our results, we suggest that infection by the protozoan may be related to environmental parasite load, regardless of the sex of the animal.

In Japanese kennels, Itoh et al. (2005) obtained 37.4\% G. duodenalis prevalence in 361 canine fecal samples, with $54.5 \%$ prevalence in pups and $30.9 \%$ prevalence in adults, without any significant difference between sexes, or between pups from positive and negative mothers. Puppy behavior may facilitate infection by more frequent contact with all types of material that may be contaminated with Giardia spp. cysts (Mundim et al. 2003). In this study, no differences in prevalence were found in the age categories, which could suggest no proclivity of the protozoan for a specific host age. Lallo et al. (2016) reported that the acquisition of intestinal mucosal immunity may be a limiting factor for the development of protozoa and may explain the decrease in parasite prevalence in adult dogs.

One of the limitations to the success of molecular techniques that use fecal material can be attributed to the low concentration of cysts. The lysis of these cysts is a critical factor for obtaining the DNA. Thus, in order to ensure a better yield of DNA from the cysts, the fecal samples must be subjected to a thermal shock 
procedure consisting of alternating cycles of freezing in liquid nitrogen $\left(-196^{\circ} \mathrm{C}\right)$ and thawing in a water bath at temperatures of up to $95^{\circ} \mathrm{C}$. This procedure can produce satisfactory results, but does not mean that $100 \%$ of the cysts can be ruptured. The total number of cysts ruptured depends on the number of cycles, thawing temperature, duration of each temperature cycle, and also number of cysts present in the sample (parasitic load) (David et al. 2011). We used thermal shock to increase the amount of DNA recovered from the samples in order to obtain a suitable yield of DNA for the nested-PCR.

To minimize the effect of DNA inhibitors, an alternative is the use of commercial kits that include extraction columns (spin columns) for the purification of DNA. Extraction by these kits may reduce the number of inhibitors present, in addition to allowing greater efficiency in obtaining the DNA sample (Gelanew et al. 2007). In the present study, we used a commercial kit to extract total DNA from the protozoan in order to minimize the effects of the PCR reaction inhibitors and ensure a sample of higher purity.

The presence of inhibitors in feces is one of the main factors that affects the efficiency of molecular techniques, and may result in the non-amplification of the gene fragments. These inhibitors include substances such as polysaccharide complexes, bile salts, bilirubin and hemoglobin degradation products. In addition to the diversity of PCR inhibitors in the feces, the concentration of these substances in the sample varies according to the consistency of the feces, diet and health status of the host (Gonçalves et al. 2008). In the present study, further tests were performed to evaluate whether PCR inhibitors could be influencing negative results in the nested-PCR.

The identification of $G$. duodenalis assemblages is based on molecular biology, such as PCR and its variations, followed by nucleic acid sequencing. These assays have emerged as an efficient alternative for the differentiation and characterization of these agents (Feng \& Xiao 2011, Koehler et al. 2014). This molecular identification has enabled and revolutionized the understanding of taxonomy, genetic diversity and epidemiology of giardiasis in humans and animals (Geurden et al. 2010).

The $\beta$-giardin $(\mathrm{bg})$ gene is a common marker of Giardia spp., and is in addition, a good marker for G. duodenalis genotyping and sub-genotyping and it has the advantage of being considered exclusive of this parasite (Read et al. 2004). In this study, six sequences of $G$. duodenalis isolates were classified in assemblage $C$ and four sequences were classified in assemblage D (Fig.1). In former studies, canine isolates from Canada were found to predominantly belong to assemblages C, D and G (McDowall et al. 2011), whereas assemblages $\mathrm{C}$ and $\mathrm{D}$ were the most common in isolates in dogs from Asia and Europe (Berrilli et al. 2012, Li et al. 2012). Assemblages $\mathrm{C}$ and $\mathrm{D}$ can be found in atypical hosts, such as humans, usually in concomitant form with other diseases (Soliman et al. 2011, Broglia et al. 2013).

The results of the current study demonstrate that this important enteric protozoan occurs independently of the sample collection site, sex and age of the dogs. Therefore, it is essential to practice measures to control and prevent this disease in companion animals. Because of the proximity of the pets to their owners, co-infection can occur with other zoonotic genotypes, including $\mathrm{A}$ and $\mathrm{B}$, which can increase the risk of transmission of $G$. duodenalis to the human.

\section{CONCLUSIONS}

The coproparasitological technique and the nested-PCR showed similar sensitivities in the diagnosis of canine giardiasis.

Giardia duodenalis occurs regardless of the population of dogs studied, sex, origin of the samples and age.

Assemblages C and D identified in this research are commonly found in dogs. Although this study did not indicate the prevalence of the zoonotic assemblages A and B in these canine isolates, it is important to introduce prophylactic measures against the infection and dissemination of the disease agent of $G$. duodenalis among the canine populations.

Compliance with ethical standards.- This study was approved by the Ethics Committee on the Use of Animals (CEUA-UFSM) No. 7028020318, on April 12, 2018.

Acknowledgments.- The authors would like to acknowledge the "Universidade Federal de Santa Maria". This study was financed in part by the "Coordenação de Aperfeiçoamento de Pessoal de Nível Superior” (CAPES), Brazil, Finance Code 001.

Conflict of interest statement.- The authors declare that they have no conflict of interest.

\section{REFERENCES}

Andresiuk M.V., Denegri G.M., Esardella N.H. \& Hollmann P. 2003. Encuesta coproparasitológico canina realizado em plazas publicas de la ciudad de Mar del Plata, Buenos Aires, Argentina. Parasitol. Latinoam. 58(1/2):17-22. <https://dx.doi.org/10.4067/S0717-77122003000100003>

Ankarklev J., Jerlström-Hultqvist J., Ringqvist E., Troell K. \& Svärd S.G. 2010. Behind the smile: cell biology and disease mechanisms of Giardia species. Nat. Rev. Microbiol. 8(6):413-422. <https://dx.doi.org/10.1038/ nrmicro2317> <PMid:20400969>

Bartmann A. \& Araújo F.A.P. 2004. Frequência de Giardia lamblia em cães atendidos em clínicas veterinárias de Porto Alegre, RS, Brasil. Ciência Rural 34(4):1093-1096. <https://dx.doi.org/10.1590/S0103-84782004000400020>

Barutzki D., Schimmel A. \& Schaper R. 2000. Eficácia de pamoato de pirantel, febantel e praziquantel contra Giardia em cães naturalmente contaminados. Bayer, Brasil, p.5-7.

Beck C., Araújo P.F.A., Olicheski A.T. \& Breyer A.S. 2005. Frequência de infecção por Giardia lamblia (Kunstler, 1882) em cães (Canis familiaris) avaliada pelo método de Faust e cols (1939) e pela coloração de auramina, no município de Canoas, RS, Brasil. Ciência Rural 35(1):126-130. <https:// dx.doi.org/10.1590/S0103-84782005000100020>

Berrilli F., D’Alfonso R., Giangaspero A., Marangi M., Brandonisio O., Kaboré Y., Glé C., Cianfanelli C., Lauro R. \& Di Cave D. 2012. Giardia duodenalis Genotypes and Cryptosporidium Species in Humans and Domestic Animals in Côte d'Ivoire: occurrence and evidence for environmental contamination. Trans. R. Soc. Trop. Med. Hyg. 106(3):191-195. <https://dx.doi.org/10.1016/j. trstmh.2011.12.005> <PMid:22265078>

Blazius R.D., Emerick S., Prophiro J.S., Romão P.R.T. \& Silva O.S. 2005. Ocorrência de protozoários e helmintos em amostras de fezes de cães errantes da Cidade de Itapema, Santa Catarina. Revta Soc. Bras. Med. Trop. 38(1):73-74. <https://dx.doi.org/10.1590/S0037-86822005000100018>

Brinker J.C., Teixeira M.C. \& Araújo F.A.P. 2009. Ocorrência de Giardia sp. em cães e gatos no município de Caxias do Sul/RS. Revta FZVA 16(1):333-334.

Broglia A., Weitzel T., Harms G., Cacció S.M. \& Nöckler K. 2013. Molecular typing of Giardia duodenalis isolates from German travellers. Parasitol. Res. 112(10):3449-3456. <https://dx.doi.org/10.1007/s00436-013-3524-y> $<$ PMid:23892479>

Cacciò S.M. \& Ryan U. 2008. Molecular epidemiology of giardiasis. Mol. Biochem. Parasitol. 160(2):75-80. <https://dx.doi.org/10.1016/j. molbiopara.2008.04.006> <PMid:18501440> 
Cacciò S.M. 2015. Giardiasis: a zoonotic infection or not?, p.821-848. In: Sing A (Ed.), Zoonoses: infections affecting humans and animals. Springer, Heidelberg.

Cacciò S.M., de Giacomo M. \& Pozio E. 2002. Sequence analysis of the $\beta$-giardin gene and development of a PCR-RFLP assay to genotype Giardia duodenalis cysts from human faecal samples. Int. J. Parasitol. 32(8):1023-1030. <https://dx.doi.org/10.1016/s0020-7519(02)00068-1><PMid:12076631>

Collins G.H., Pope S.E., Griffn D.L., Walker J. \& Connor G. 1987. Diagnosis and prevalence of Giardia sp. in dogs and cats. Aust. Vet. J. 64(3):89-90. <https:// dx.doi.org/10.1111/j.1751-0813.1987.tb09628.x><PMid:3579759>

David E.B., Coradi S.T., Oliveira-Sequeira T.C.G., Ribolla P.E.M., Katagiri S. \& Guimarães S. 2011. Diagnosis of Giardia infections by PCR-based methods in children of an endemic area. J. Venom. Anim. Toxins Incl. Trop. Dis. 17(2):209-215. <https://dx.doi.org/10.1590/S1678-91992011000200012>

Faubert G. 2000. Immune response to Giardia duodenalis. Clin. Microbiol. Rev. 13(1):35-54. <https://dx.doi.org/10.1128/cmr.13.1.35-54.2000> $<$ PMid:10627490>

Faust E.C., Sawitz W., Tobie J., Odom V., Peres C. \& Lincicome D.R. 1939. Comparative efficiency of various techniques for the diagnosis of protozoa and helminthes in feces. J. Parasitol. 25(3):241-262. <https://dx.doi. org/10.2307/3272508>

Felsenstein J. 1985. Confidence limits on phylogenies: an approach using the bootstrap. Evolution 39(4):783-791. <https://dx.doi org/10.1111/j.1558-5646.1985.tb00420.x> <PMid:28561359>

Feng Y. \& Xiao L. 2011. Zoonotic potential and molecular epidemiology of Giardia species and giardiasis. Clin. Microbiol. Rev. 24(1):110-140. <https://dx.doi. org/10.1128/CMR.00033-10><PMid:21233509>

Gelanew T., Lalle M., Hailu A., Pozio E. \& Cacciò S.M. 2007. Molecular characterization of human isolates of Giardia duodenalis from Ethiopia. Acta Trop. 102(2):92-99.<https://dx.doi.org/10.1016/j.actatropica.2007.04.003> $<$ PMid:17498637>

Geurden T., Vercruysse J. \& Claerebout E. 2010. Is Giardia a significant pathogen in production animals? Exp. Parasitol. 124(1):98-110. <https://dx.doi org/10.1016/j.exppara.2009.03.001> <PMid:19285075>

Gonçalves E.M., Araújo R.S., Orban M., Matté G.R., Matté M.H. \& Corbett C.E.P. 2008. Protocol for DNA extraction of Cryptosporidium spp. oocysts in fecal samples. Revta Inst. Med. Trop. S. Paulo 50(3):165-167. <https://dx.doi. org/10.1590/S0036-46652008005000002>

Horejs R. \& Koudela B. 1994. Giardiasis in dogs in a breeding kennel. Vet. Med. 39(2/3):93-101. <PMid:8184530>

Itoh N., Muraoka N., Saeki H., Aoki M. \& Itagaki T. 2005. Prevalence of Giardia intestinalis infection in dogs of breeding kennels in Japan. J. Vet. Med. Sci. 67(7):717-718. <https://dx.doi.org/10.1292/jvms.67.717> <PMid:16082121>

Joffe D., Van Niekerk D., Gagné F., Gilleard J., Kutz S. \& Lobingier R. 2011. The prevalence of intestinal parasites in dogs and cats in Calgary, Alberta. Can. Vet. J. 52(12):1323-1328. <PMid:22654137>

Jukes T.H. \& Cantor C.R. 1969. Evolution of protein molecules, p.21-132. In: Munro H.N. (Ed.), Mammalian Protein Metabolism. Academic Press, New York.

Katagiri S. \& Oliveira-Sequeira T.C. 2008. Prevalence of dog intestinal parasites and risk perception of zoonotic infection by dog owners in São Paulo State, Brazil. Zoonoses Public Health 55(8/10):406-413.<https://dx.doi. org/10.1111/j.1863-2378.2008.01163.x> <PMid:18811905>

Koehler A.V., Jex A.R., Haydon S.R., Stevens M.A. \& Gasser R.B. 2014. Giardia/ giardiasis: a perspective on diagnostic and analytical tools. Biotechnol. Adv. 32(2):280-289. <https://dx.doi.org/10.1016/j.biotechadv.2013.10.009> $<$ PMid:24189092>

Kumar S., Stecher G., Li M., Knyaz C. \& Tamura K. 2018. MEGA X: molecular evolutionary genetics analysis across computing platforms. Mol. Biol. Evol. 35(6):1547-1549. <https://dx.doi.org/10.1093/molbev/msy096> $<$ PMid:29722887>
Lalle M., Pozio E., Capelli G., Bruschi F., Crotti D. \& Cacciò S.M. 2005. Genetic heterogeneity at the $\beta$-giardin locus among human and animal isolates of Giardia duodenalis and identification of potentially zoonotic subgenotypes. Int. J. Parasitol. 35(2):207-213. <https://dx.doi.org/10.1016/j. ijpara.2004.10.022> <PMid:15710441>

Lallo M.A., Spadacci-Morena D.D. \& Coutinho S.D.A. 2016. Comportamento humano na criação de cães e a prevalência de parasitos intestinais com potencial zoonótico. Revta Acad. Ciênc. Anim. 14:119-128. <https://dx.doi. org/10.7213/academica.14.2016.13>

Li J., Zhang P., Wang P., Alsarakibi M., Zhu H., Liu Y., Meng X., Li J., Guo J. \& Li G. 2012. Genotype identification and prevalence of Giardia duodenalis in pet dogs of Guangzhou, Southern China. Vet. Parasitol. 188(3/4):368-371. <https://dx.doi.org/10.1016/j.vetpar.2012.04.004> <PMid:22554420>

Marcel A.M., Manso E.O., Pêrez H.S., Hernández O.G. \& Melendéz J.A.S. 1994. Frecuencia de giardiasis en algunas especies de animales domésticos de la provincia de Villa Clara, Cuba. Vet. Méx. 25(4):337-340.

McDowall R.M., Peregrine A.S., Leonard E.K., Lacombe C., Lake M., Rebelo A.R. \& Cai H.Y. 2011. Evaluation of the zoonotic potential of Giardia duodenalis in fecal samples from dogs and cats in Ontario. Can. Vet. J. 52(12):1329-1333. <PMid:22654138>

Mundim J.S.M., Cabral D.D. \& Faria E.S.M. 2001. Endoparasitas de importância como zoonoses em fezes de cães domiciliados de Uberlândia, Minas Gerais. Vet. Notícias 7:73-77.

Mundim M.J.S., Souza S.Z., Hortêncio S.M. \& Cury M.C. 2003. Frequência de Giardia spp. por duas técnicas de diagnóstico em fezes de cães. Arq. Bras. Med. Vet. Zootec. 55(6):770-773. <https://dx.doi.org/10.1590/S0102$09352003000600016>$

Nikolic A., Kulisic Z. \& Bojkovski J. 1993. Giardiasis as a zoonosis: the prevalence of Giardia in dogs in Belgrade. Acta Vet. 43(4):239-243.

Oliveira-Sequeira T.C, Amarante A.F., Ferrari T.B. \& Nunes L.C. 2002. Prevalence of intestinal parasites in dogs from São Paulo State, Brazil. Vet. Parasitol. 103(1/2):19-27. <https://dx.doi.org/10.1016/s0304-4017(01)00575-1> <PMid:11750997>

Plutzer J., Ongerth J. \& Karanisc P. 2010. Giardia taxonomy, phylogeny and epidemiology: facts and open questions. Int. J. Hyg. Environ. Health 213(5):321-333. <https://dx.doi.org/10.1016/j.ijheh.2010.06.005> <PMid:20619729>

R Core Team 2016. R: a language and environment for statistical computing. R Foundation for Statistical Computing, Vienna, Austria. Available at <https://www.R-project.org/> Accessed on Nov. 25, 2020

Read C.M., Monis P.T. \& Thompson R.C. 2004. Discrimination of all genotypes of Giardia duodenalis at the glutamate dehydrogenase locus using PCRRFLP. Infect. Genet. Evol. 4(2):125-130. <https://dx.doi.org/10.1016/j. meegid.2004.02.001><PMid:15157630>

Ryan U. \& Cacciò S.M. 2013. Zoonotic potential of Giardia. Int. J. Parasitol. 43(12/13):943-956.<https://dx.doi.org/10.1016/j.ijpara.2013.06.001> <PMid:23856595>

Saitou N. \& Nei M. 1987. The neighbor-joining method: a new method for reconstructing phylogenetic trees. Mol. Biol. Evol. 4(4):406-425. <https://dx.doi.org/10.1093/oxfordjournals.molbev.a040454> $<$ PMid:3447015>

Silva A.S., Ceolin L.V., Cargnelutti J.F., Pessoa G.A., Oliveira C.B., Quintal A.P.N. \& Monteiro S.G. 2007. Prevalência de parasitismo em cães domiciliados num bairro de Santa Maria-RS. Revta Saúde, Santa Maria, 33(1):27-31. <https://dx.doi.org/10.5902/223658346460>

Soliman R.H., Fuentes I. \& Rubio J.M. 2011. Identification of a novel Assemblage B subgenotype and a zoonotic Assemblage C in human isolates of Giardia intestinalis in Egypt. Parasitol. Int. 60(4):507-511. <https://dx.doi. org/10.1016/j.parint.2011.09.006><PMid:21989040>

Thompson R.C., Hopkins R.M. \& Homan W.L. 2000. Nomenclature and genetic groupings of Giardia infecting mammals. Parasitol. Today 16(5):210-217. <https://dx.doi.org/10.1016/s0169-4758(99)01624-5><PMid:10782081> 